Recombinant DNA guidelines wear thin

NIH moves

\section{to voluntary}

\section{regulation}

\section{Washington}

The US National Institutes of Health (NIH) have taken the first steps towards removing mandatory controls on the conduct of recombinant DNA research. Meeting in Bethesda, Maryland, the institutes' Recombinant DNA Advisory Commitee (RAC) set up a subcommittee to discuss whether the present guidelines, which all federally-sponsored scientists have to observe, should be turned into a voluntary code of practice, and the answer is likely to be yes.

The committee's decision was in response to a proposal from two of its members, Dr Allan Campbell of Stanford University and Dr David Baltimore of the Massachusetts Institute of Technology. They suggested that the guidelines should be voluntary - eliminating the formal need for review bodies such as local Institutional Biosafety Committees - and that there should be major reductions in the containment levels recommended for various types of experiments (Nature 26 March, p.281).

Their proposal, which was published in the Federal Register on 20 March and would involve eliminating virtually all the regulatory requirements contained in Part III of the current guidelines, has generated considerable support in the scientific community.

Most members of the committee seemed to agree with the spirit of the proposition. Their willingness to relax the guidelines was illustrated in an earlier vote on reducing containment requirements for experiments involving Escherichia coli $\mathrm{K} 12$ and laboratory strain Saccharomyces cerevisiae host vector systems. The committee adopted the most liberal option, recommending that such experiments, making up about 80 per cent of al recombinant DNA experiments, be totally exempted from the guidelines.

Several committee members pointed out, however, that there is still considerable public concern about the potential social effects of recombinant DNA research. Hence should such research be regulated, it must be seen to be done in a responsible manner as otherwise federal or state legislation might be provoked. Other members, particularly those from the public interest community, argued against reducing the containment conditions too quickly, pointing out that although a few experiments seemed to confirm that recombinant DNA experiments posed no greater risks than other experiments with the same organisms, this hypothesis had not yet been rigorously tested. Even $\mathrm{Dr}$ Campbell and Dr Baltimore agreed that experiments over 10 litres should still be subject to special review by the director of NIH, since large-scale experiments might still result in unsuspected hazards.

The committee members finally agreed that, rather than recommending to $\mathrm{NIH}$ director Dr Donald Fredrickson the immediate transmutation of the guidelines from formal restrictions into a voluntary code of practice, a subcommittee should look into the whole question of the future of the guidelines.

The proposal made by Dr Campbell and Dr Baltimore would result in the recommendation that most experiments involving recombinant DNA be carried out in P1 containment conditions, these representing prudent laboratory practice. Potentially hazardous microorganisms would be classified and handled according to procedures recommended by the Center for Disease Control (CDC) in Atlanta, Georgia. Several scientists have expressed concern about proposed revisions to these procedures, published by CDC last year, arguing that in certain cases they would be more restrictive than necessary. However, Dr Baltimore told the committee that he believed CDC "will eventually produce a document that is a useful guide to the appropriate laboratory practice".

Dr Baltimore also stressed that RAC would still be needed to maintain surveillance over recombinant DNA research in the future, to make decisions about

\section{Role of advisory committee questioned}

The United Kingdom's Advisory Board for the Research Councils could provide government with advice on a wide range of public policy issues with a scientific content if its terms of reference were extended, according to its chairman, Sir Alec Merrison. At present, the board is constrained by its remit to advise the Secretary of State for Education and Science chiefly on the distribution of the science vote amongst the research councils.

The board is like a "huge torpedo" that is not being launched "at anything very much" Sir Alec told the House of Lords Select Committee on Science and Technology last month as part of its investigation into the provision of scientific advice to government. The expertise of the board's members, senior scientists and administrators, could be put to better use if it took on a role similar to the Advisory Council on Scientific Policy, which provided advice on science policy through a chief scientist to the government before its demise in 1963. Any extension of the board's remit, however, would require very careful thought, said Sir Alec, to avoid

\section{Plea to keep guidelines}

A report published by the Office of Technology Assessment, after a two-year study of the impact of applied genetics, says that there are several reasons for not eliminating the guidelines completely, pointing out that "sufficient scientific concern exists for the guidelines to prohibit certain experiments and to retain containment for others", and that most experiments can already be carried out at the least burdensome containment levels.

Although conceding that $\mathrm{NIH}$ showed flexibility in liberalizing the restrictions as evidence showed lower risk levels than originally feared, there is criticism of the way that NIH have played the role of oversight body. Several shortcomings are listed, including the virtual non-existence of monitoring for compliance to the guidelines, and the lack of systematic evaluation of other techniques, such as cell fusion, that might present risks.

The report, which lists some of the many applications of recombinant DNA techniques in a wide range of industries, says that Congress might wish to consider the need for regulating work with all hazardous microorganisms and viruses, whether or not they are products of genetic engineering.

experiments which may present particular dangers and to help in the evaluation of ethical issues, which were going to become a very important part of a recombinant DNA activities.

David Dickson

treading on the toes of the Advisory Council for Applied Research and Development which does a good job in advising on scientific aspects of industrial policy.

Informal contact with the Department of Education and Science was generally good, Sir Alec said. But it had not worked in the case of the government's White Paper on public expenditure, published on budget day last March. Although the implications of the White Paper for the support of basic science in the universities were "profound", the board only learnt of the government's plans in a brief letter a few days before the budget statement.

Sir Alec said that by thinking that it could protect science by maintaining the level of the science vote while considerably reducing the grant for student fees, the government had clearly not understood the way in which university science is funded. The implications for that system, known as the dual support system, are so grave, said Sir Alec, that work on a report that the board is preparing into its workings has had to stop. 